\title{
The Last Door: Political Prisoners and the Use of Torture in Mexico's Dirty War
}

I n December 1969, former President Lázaro Cárdenas sent a letter to political prisoners in the Lecumberri federal penitentiary in Mexico City, assuring them that he would continue to lobby for their release. ${ }^{1}$ In October 1973, Michoacán university students marching in front of the state government building in Morelia held up placards demanding the release of political prisoners. ${ }^{2}$ On June 29, 1974, Lucio Cabañas, guerrilla leader of the Partido de los Pobres (Party of the Poor) in the mountains of Guerrero, released a communiqué in which the group's first demand was the release of political prisoners. ${ }^{3}$ In its founding document from March 1973, the Liga Comunista 23 de Septiembre (LC-23S), an urban-based guerrilla group responsible for more than 60 direct-action operations, made it clear that political prisoners were one of the costs of carrying out a revolution and, as such, would not distract from its broader mission. ${ }^{4}$ These are just some of the references to the imprisonment of activists during the height of what is considered Mexico's dirty war. Taken together, the many references to political prisoners suggest that being held captive by the state was a common threat and, in some cases, a reality in the lives of those challenging the authoritarian government in the 1960s and 1970s.

This article is a broad look at the experiences of Mexico's political prisoners, primarily in the 1970s. It includes the cases of the 1968 student movement but departs from them to focus on subsequent cases of urban guerrilla members who suffered the full force of torture and remained in prison for much longer than those involved in the student movement. By way of a disclaimer, the

\footnotetext{
The author would like to thank the two anonymous readers, Hugo Velázquez, Steve Stern, Jaymie Heilman, Solsiree Del Moral, Matthew Cleary, Rafael Fernández de Castro, Norman Kutcher, and Frederick Marquardt for their invaluable support and feedback.

1. Archivo General de la Nación [hereafter AGN], Dirección Federal de Seguridad [hereafter DFS], exp. 10014-1-69, leg. 18, p. 276 (December 19, 1969).

2. AGN DFS, exp. 100-14-1, leg. 24, p. 19 (October 3, 1973).

3. http://nsarchive.gwu.edu/NSAEBB/NSAEBB105/Docl5.pdf, accessed November 7, 2016.

4. https://ligacomunista23.files.wordpress.com/2015/05/cuestiones09.pdf, accessed November 7, 2016.
} 
article makes only make passing mention of what took place in Guerrero during this decade; it is unable to do justice to the scope of what political prisoners endured here. ${ }^{5}$ The analysis herein is also limited to the imprisonment and torture of individuals.

The frequency with which the subject of political prisoners was addressed among groups opposing the PRI is jarring when read against the official common sense of the time. After all, party leaders in the aftermath of the 1910 Revolution, had ostensibly ushered in a political system that, though imperfect, promised a modicum of social peace and gradual modernization. These promises appeared on path to becoming a reality during the 1940s and 1950s, with strong economic growth rates and the advent of what has been referred to as the Golden Age for modern Mexico. The 1960s witnessed greater unrest from a range of social sectors, including students and, after 1965, guerrilla groups demanding a democratic opening. Yet, the Mexican government, while violent in its response to the 1968 student mobilizations and its battles with guerrilla groups in the 1970s, was not as violent as the military governments carrying out "dirty wars" against similar groups in many South American countries at the time. Wil Pansters has stated that so much attention has been focused on distinguishing Mexico's “moderate authoritarianism” from other cases of repressive regimes in Latin America that it has "unintentionally contributed to underestimating or masking violence and coercion-the "dark side“-in state-making." In other words, this differential attention has fueled the misconception that the government's use of repression was not on par with that employed elsewhere in the region.

To counteract this misconception, the following pages explore the history of the "dirty war" of the 1970s. They answer a range of questions surrounding how these two repressive tools-detention and torture-helped the governing regime maintain its control at a moment of great vulnerability, especially in the face of armed guerrilla groups in both urban and rural areas. These questions range from relatively straightforward ones, such as what was it like to be a political prisoner in Mexico's penitentiary system, and the evolving profile of political prisoners, to the more difficult ones of how the government nurtured a culture of fear to intimidate what it deemed recalcitrant members of society

5. FEMOSPP, chapt. 6. Others have begun the task of documenting the scale of the dirty war in Guerrero. See Alexander Aviña, Specters of Revolution: Peasant Guerrillas in the Cold War Mexican Countryside (New York: Oxford University Press, 2014); and the Guerrero Truth Commission (Comisión de la Verdad, Guerrero), Informe Final de la Comisión de la Verdad del estado de Guerrero (Final Report from the State of Guerrero's Truth Commission), 2014, http://www.almomento.mx/images/InformeFinalCOMVERDAD.pdf, accessed November 7, 2016.

6. Wil G. Pansters, "Zones of State-Making: Violence, Coercion, and Hegemony in Twentieth-Century Mexico," in Pansters, ed., Violence, Coercion, and State-Making in Twentieth-Century Mexico: The Other Half of the Centaur (Stanford: Stanford University Press, 2012), 8 (Panster's italics). 
and, by extension, their families and friends. In answering them, the article finds, not surprisingly, that prisons, both official and clandestine, could act as a form of hybrid state institution and that the systematic use of torture helped officials rein in dissenters to further splinter an already divided left.

A seemingly contradictory looseness characterized prison life. ${ }^{7}$ On one hand, prisoners who could afford the bribes could cook their own meals, receive extended visits from family and friends, even prostitutes, and take part in educational workshops. On the other hand, the same guards who accommodated such privileges could be capriciously tough, vengeful, and brutal. What appeared to be the arbitrary use of violence inside prison walls in fact promoted a culture of fear, fortified by the common knowledge that torture had a long history inside Mexico's penal system. There was also a dawning awareness in the 1970s of the existence of new repressive techniques developed with input from outside Mexico. The article concludes that studying the continuum between political prisoners, the practices of torturing them, and the suffering imposed on their families reveals an underlying pattern that supported the governing regime's perpetration of violence: an ability to adapt to potential threats paired with the calibration of its repressive responses to make them covert.

The episodic nature of political violence, especially that designed to decimate supposed guerrilla threats to the regime in the 1970s, constituted a system of repression comparable, though not identical, to that found in the "dirty wars" of Chile, Argentina, Uruguay, and Brazil at a similar moment. As one of the investigators from the Special Prosecutors Office for Social and Political Movements of the Past (Fiscalía Especial para Movimientos Sociales y Políticos del Pasado, or FEMOSPP) stated, "Specifying Mexico's dirty war is hard." 8 The article thus posits a framework of low-intensity dirty war, because it allows for ebbs and flows across time, building up in response to immediate exigencies, such as protecting national security from a possible armed internal enemy.

This framework is flexible enough to allow for a longer periodization of the dirty war that includes three stages to tie together those ebbs and flows. The first, between 1946 and 1962, is linked to both a birth and a death. The death occurred in the massacre of several dozen civilians in León, Guanajuato, who

7. For an earlier history of this looseness surrounding prison life, see Pablo Piccato, City of Suspects: Crime in Mexico City, 1900-1931 (Durham: Duke University Press, 2001); and Carlos Aguirre, The Criminals of Lima and Their Worlds: The Prison Experience, 1850-1935 (Durham: Duke University Press, 2005).

8. Américo Meléndez Reyna, quoted in Alfonso García Morales, María de los Ángeles Magdaleno Cárdenas, Mario Ramírez Salas, and Américo Meléndez Reyna, "México: La Fiscalía Especial para los Movimientos Sociales y Políticos del Pasado," Entre la memoría y la justicia: experiencias latinoamericanas sobre guerra sucia y defensa de derechos humanos, Rubén Ruiz Guerra, ed., (Mexico City: Universidad Nacional Autónoma de México, 2005), 235. 
were protesting the official imposition of a candidate. 9 Soon after, in 1947, came the birth, that of the Federal Security Directorate (Dirección Federal de Seguridad, or DFS), the "operative” branch of the federal government's surveillance agencies-what is referred to as Mexico's secret police. This first stage saw the government experimenting with different forms of repression at the hands of state agents, primarily in the countryside and far away from the public's eye. ${ }^{10}$ The second stage, between 1962 and 1968, begins with the brutal assassination of the rural activist and ideological heir of Emiliano Zapata, Rubén Jaramillo, in Morelos, and signals the advent of more openly repressive tactics to an urban audience. It encompasses the beginning of the radical armed insurgency, with the September 23, 1965, assault by guerrilla groups of army barracks in Ciudad Madera, Chihuahua, and the military's heavy-handed reaction that left many dead.

The third and most violent stage began with the rise of the student mobilizations in Mexico City during the spring and summer of 1968, culminating with the massacre of October 2, and concluded in 1982 when no remnants remained of any guerrilla or effective leftist group to challenge the government. In this stage, the dirty war extended to urban as well as rural areas and involved much more violent tactics, akin to what we see in other dirty wars in the region. Illegal imprisonment, torture, and disappearance, though present in the previous two stages, became part of a systematic and more strategically deployed repressive arsenal of a state caught up in the throes of battles with assorted guerrilla groups. ${ }^{11}$ As in the Southern Cone, Mexican officials opted for a hard-line response to popular challenges, intending to nurture a culture of fear as a way to rein in dissent. The government's torture and detention of activists - those they referred to as subversives-was a key component in

9. Daniel Newcomer, Reconciling Modernity: Urban State Formation in 1940s León, Mexico (Lincoln: University of Nebraska Press 2004), 143-176.

10. I develop the arguments for this first stage in Gladys McCormick, The Logic of Compromise in Mexico: How the Countryside was Key to the Emergence of Authoritarianism (Chapel Hill: University of North Carolina Press, 2016).

11. See for example Marco Bellingeri, Del agrarismo armado a la guerra de los pobres, 1940-1974 (Mexico City: Ediciones Casa Juan Pablos; Secretaría de Cultura de la Ciudad de México, 2003); Fernando Herrera Calderón and Adela Cedillo, Challenging Authoritarianism in Mexico: Revolutionary Struggles and the Dirty War, 1964-1982 (New York: Taylor and Francis Group, 2012); Barry Carr, Marxism and Communism in TwentiethCentury Mexico (Lincoln: University of Nebraska Press, 1992); Laura Castellanos, México armado, 1943-1981 (Mexico City: Ediciones Era, 2007); Comisión Nacional para los Derechos Humanos-Mexico (CNDH), Informe especial sobre las quejas en materia de desapariciones forzadas ocurridas en la década de los 70 y principios de los 80 (2001), www.cndh.org.mx/sites/all/doc/Informes/Especiales/2001_Desapariciones70y80.pdf; Fiscalía Especial para Movimientos Sociales y Políticos del Pasado, "Borrador del Informe de la Guerra Sucia" (2006) [Because the final report was heavily redacted, researchers rely on the draft report as the more reliable of the two versions.], http://nsarchive.gwu.edu/NSAEBB/NSAEBB180/index2.htm; Fritz Glockner Corte, Memoria roja: historia de la guerrilla en México (1962-1968) (Mexico City: Ediciones B, 2007); Jaime López, Diez años de guerrillas en México (Mexico City: Editorial Posada, 1974); Carlos Montemayor, La guerrilla recurrente (Mexico City: Editorial Debate, 2007); and Verónica Oikión Solano and Marta Eugenia García Ugarte, eds. Movimientos armados en México, siglo xx, 13 vols. (Zamora, Michoacán: Colegio de Michoacán, CIESAS, 2006). 
creating this culture of fear: though it was intended to appear as clandestine, the population at large knew it was taking place. What appeared to be looseness in prison life, the fact that those targeted were housed in the same facility with other prisoners, and the increasing human rights activism of political prisoners' families disseminated knowledge of what was taking place. Yet, the government capitalized on its use of torture with the justification that it had to undermine the established rule of law to deal with an unconventional enemy, whether armed or not, that threatened the social fabric. It also capitalized on the fact that torture was a historically established practice inside Mexico's prisonsthereby creating an ambiguity that allowed for the increased use of "enhanced" repressive techniques in rooting out subversives.

Even this more violent stage had its own ebbs and flows. By the time it began, the Mexican government already had a long record of imprisoning dissidents. Demetrio Vallejo, the railroad leader, and David Alfaro Siqueiros, the muralist and known Communist, are among the best known of this earlier generation of political prisoners. ${ }^{12}$ Nevertheless, focusing on the third stage shows a dramatic shift in what it meant to be a political prisoner. No longer were their ranks primarily made up of labor, intellectual, and rural leaders. They now included women, younger members of an emerging urban and educated middle class, and family members of activists. The types of torture employed against suspected guerrilla members became more brutal than those used against the 1968 activists. As this stage progressed, this change in tactics took an ominous turn: activists had been routinely imprisoned and tortured, but government agents now realized that they could more easily and expediently disappear insurgents under the banner of impunity and Cold War paranoia. This aspect of the dirty war-the disappearing and killing of so-called subversives-was known only partially at the time and the fragmented impression made what was happening to these protestors all the more ominous and intimidating.

The elusive nature of Mexico's dirty war extends to the numbers of victims and the language used to legitimate the government's repression. Because there has been no autonomous and adequately funded truth commission similar to those established in Guatemala, Peru, or South Africa, we do not know the full extent of the violence in Mexico. Even the researchers of the FEMOSPP concluded they were unable to ascertain precise numbers; in 2007, their funding was cut off and their office dissolved before any perpetrators could be prosecuted. ${ }^{13}$ Some scholars have proposed rough figures for the number of victims between

12. For more on the imprisonment of Siqueiros, Vallejo, and others in the earlier part of the 1960 s, see Enrique Condés Lara, Represión y rebelión (1959-1985), and La guerra fría en México: el discurso de la repression (Puebla: Benemérita Universidad Autónoma de Puebla, 2007), vol. 1, 125-190.

13. La Jornada, March 27, 2007. 
1964 and 1982: approximately 7,000 people tortured, at least 3,000 political prisoners, and more than 3,000 disappeared or killed. ${ }^{14}$ However, there are still outstanding questions and insufficient concrete documentation to cite definite figures.

Many of these victims, especially the disappeared, came from the state of Guerrero and belonged to two guerrilla groups; nevertheless, the violence stretched to other locales in central and north-central Mexico, including Mexico City, Monterrey, and Guadalajara, with the rise of urban guerrilla groups. We have yet to ascertain the breakdown of among rural and urban victims, though it clearly skews toward larger numbers in rural areas. The elusiveness extends to the language in documents found in official government files. The DFS documents, while descriptive and thorough in regard to the information collected, adopt a vague tone when relating how the information was acquired: for example, agents "applied pressure," or guerrilla members "provided" or "manifested" information after a preliminary interrogation. ${ }^{15}$ One FEMOSPP official noted that Mexican officials avoided the term "torture," preferring such phrases as "the detained were interrogated"; but then added: "You only have to look at photographs after these interrogations to know how this was carried out."16

There were three possible outcomes after an individual was tortured in a clandestine prison: they would be released, transferred to an established prison for longer detention, or disappeared. As the Comisión Nacional para los Derechos Humanos (National Commission for Human Rights, or CNDH) investigators found out, the pattern culminating in the disappearance of political prisoners can be seen in hundreds, if not thousands, of cases. ${ }^{17}$ Taken together, the detention of activists, their ensuing torture, and the various possible outcomes drew strength from one another, nurturing a culture of fear in the post-1968 period. This story relies on declassified intelligence reports from Mexico and the United States, human rights reports, and numerous testimonies with victims. These testimonies include extended

14. These figures can be found in Calderón and Cedillo, Challenging Authoritarianism, 8 . They relied on the $\mathrm{CNDH}$ report (which lists 532 cases of verified disappearances, but left the remaining standing for additional research), as well as the reports of other human rights groups, including the Asociación de Familiares de Detenidos Desaparecidos y Víctimas de Violaciones a los Derechos Humanos en México.

15. Sergio Aguayo, La charola: una historia de los servicios de inteligencia en México (Mexico City: Editorial Grijalbo, 2001), 185; AGN DFS, 100-12, leg. 2, pp. 74, 134-141 (October 12, 1977); exp. 11-235, leg. 36, p. 76 (March 15, 1976); exp. 11-235, leg. 43, p. 160 (April 17, 1977); exp. 11-235, leg. 46, p. 1 (July 9, 1977).

16. María de los Ángeles Magdaleno Cárdenas quoted in Ruiz Guerra, Entre la memoría y la justicia, 233. This reliance on euphemisms was by no means unique to Mexico. See for example Marguerite Feitlowitz, A Lexicon of Terror: Argentina and the Legacies of Torture, 2nd ed. (New York: Oxford University Press, 2012); and Rita Maran, Torture: The Role of Ideology in the French-Algerian War (New York: Praeger, 1989).

17. $\mathrm{CNDH}$, Informe especial. 
interviews gathered in service of this article with two former political prisoners, herein referred to by their pseudonyms, Saúl and Bernardo, to protect their privacy. ${ }^{18}$

\section{INSIDE THE PRISON}

Throughout the dirty war's three stages, the government used both legal and extralegal tools to imprison political activists. From 1941 until it was repealed in 1970, the majority of political prisoners were charged with violating Article 145 of the Federal Penal Code, which targeted anyone deemed a threat to public order by way of acts of "social dissolution."19 The law came to symbolize the arbitrary and repressive side of the Mexican government. Activists and their family members lobbied for the article's revocation, calling it "unconstitutional," a detriment to "free speech," and a "hindrance to democratic values." ${ }^{20}$ Even though they succeeded at revoking Article 145 in 1970, the government did not cease manipulating the law and related means to imprison activists. Officials continued to apply existing laws against rebellion and sedition such as Article 144. They retooled other national security laws to target activists, including Article 139 and its definition of terrorism as "acts against persons, objects, or public services that produce alarm, fear or terror." 21 In 1972, the Topo Chico prison in Nuevo León housed 23 "subversive elements" charged with "carrying illegal weapons, criminal association, disobeying and resisting public functionaries, threats, assault, murder, false imprisonment, robbery, and property damage." 22 Activists could be detained on charges with no legal foundation, including being a "subversive," "professional agitator," "guerrilla," or "communist," or having contact with any person with the aforementioned labels. One DFS file from Oblatos penitentiary in Guadalajara in May 1978 cites the names of six political prisoners detained without any formal charges for "security measures."23

18. The interviews with Saúl and Bernardo were carried out over several days in May 2014 at their homes in Mexico City. The two men each spent more ten years in prison, beginning in the early to mid 1970s, and belonged to two different guerrilla organizations. Despite the fact that both are in the official record with their guerrilla activities, I chose to conceal their identities because of the sensitivity of the information pertaining to their time as political prisoners. Rather than footnote every instance, I draw from their interviews together, and signal in the text which interviewee is the source of a given piece of information. Unless specified otherwise, all translations are my own.

19. Halbert Jones, "Social Dissolution: Article 145 of the Mexican Federal Penal Code in International Context, 1941-1970," paper presented at the Boston Area Latin American History Workshop, Cambridge, MA, April 2009.

20. Letter to the Mexican Congress from the wives and mothers of 80 political prisoners (November 22, 1962), Centro de Estudios del Movimiento Obreros y Socialista, box 1475-A, exp. 17 F 11

21. Código Penal Federal 2013, p. 32. The use of false evidence was a longstanding practice. For instance, see Los procesos de México 68: la criminalización de las víctimas (Mexico City: Comité 68 por Libertades Democráticas, 2008).

22. AGN DFS, exp. 100-17, leg. 28, p. 228 (April 8, 1972).

23. AGN DFS, exp. 11-122, leg. 14, p. 49 (May 12, 1978). 
On arrest, political prisoners were taken to both official and clandestine government installations throughout the country. DFS files for the 1970s contain lists of "subversives" then incarcerated for their political activities. ${ }^{24}$ The numbers varied across the decade, as arrests increased and officials relocated prisoners to different facilities to prevent them from organizing. ${ }^{25}$ Though the majority of prisoners were housed in the Lecumberri penitentiary in Mexico City, there were also groups scattered in other state penitentiaries. ${ }^{26}$ Several of the 16 political prisoners in the Sonora penitentiary, including four women, belonged to the group LC-23S and were serving terms ranging from nine to 30 years for their guerrilla activities. ${ }^{27}$ Aside from Lecumberri, Oblatos, and Topo Chico, political prisoners were also incarcerated in the Reclusorio Oriente in Mexico City, the Islas Marías Federal Penal Colony off the coast of Nayarit, and Santa Martha Acatitla in the state of Mexico. Some political prisoners spent time in detention centers within military bases, such as Campo Militar-1 (CM-1) in Mexico City and the air base in Pie de la Cuesta, Guerrero, which operated in a more clandestine fashion than traditional prisons.

It was from these clandestine prisons that many political prisoners were subsequently disappeared. Though there was some crossover inside traditional prisons, according to Bernardo, officials tended to segregate political prisoners from what they referred to as common prisoners (presos comunes) by keeping them in separate cellblocks. In Lecumberri, Bernardo remembered, political prisoners occupied the $\mathrm{M}, \mathrm{J}$, and O blocks of the building. A DFS report from 1969 gave a more precise breakdown: of the 3,000 plus inmates at Lecumberri, 334 were political prisoners, most of whom were housed in the $\mathrm{C}$ and $\mathrm{M}$ blocks. ${ }^{28}$ Those wings reserved for political prisoners were further divided depending on the sort of activity with which the person was purportedly involved. For example, activists belonging to the 1968 student movement were housed exclusively in the $\mathrm{M}$ block. Each cell contained at least two prisoners, though some housed up to five or six.

The arrival of a new political prisoner to Lecumberri was met with questions from fellow prisoners asking what books they had read, to determine their level of education and to what group they belonged and to see with whom they would socialize. As Bernardo described it, "Prison was like a micro-society; the

24. For example, AGN DFS, exp. 11-4-69, leg. 98, pp. 79-84 (October 23, 1969), lists 200 political prisoners housed in Lecumberri.

25. AGN DFS, exp. 11-235, leg. 23, p. 211 (January 12, 1974); exp. 100-5, leg. 32, p. 344 (December 20, 1971).

26. AGN DFS, exp. 100-24, leg. 24306 (August 25, 1975); exp. 100-17, leg. 28, p. 228 (April 8, 1972); exp. 11-235, leg. 30, p. 15 (June 10, 1975).

27. AGN DFS, exp. 11-235, leg. 26, p. 81 (April 18, 1975).

28. AGN DFS, exp. 53-2, leg. 1, pp. 65-71 (September 30, 1969). 
individual didn't matter, it was the group that mattered." Each group had its own routine and rules. Those prisoners belonging to the Revolutionary Action Movement (MAR) were among the most regimented. Every day followed a set plan, from the moment they woke up until they went to bed, with activities such as study groups, workshops, and exercise sessions. Even for those not regimented so strictly as those belonging to the MAR, Bernardo reported, being a political prisoner in Lecumberri was like "going to school." Adolfo Gilly agreed with Bernardo's thought in the acknowledgments of his post-incarceration book La revolución interrumpida, where he thanked others imprisoned in Lecumberri for his political education. ${ }^{29}$ Bernardo and his comrades edited a magazine, wrote poetry, ran workshops, and read vast numbers of books on a wide range of topics. Prison "made me more disciplined, organized. I started cooking." This educational aspect extended throughout the country's penitentiaries. Following a raid on political prisoners' cells in September 1975, Acapulco penitentiary officers confiscated contraband that included shivs, marijuana, and "ideologically leftist books and writings" such as Who Is Lucio Cabañas by José Natividad Rosales and On War by Karl Von Clause $[\mathrm{sic}] .{ }^{30}$ In addition to the contraband, prison officials listed the titles of educational workshops offered by political prisoners, which included sessions on philosophy, political economy, and military theory and tactics. ${ }^{31}$

Upon arrival, as Bernardo describes, prisoners also learned quickly how officials inside the prison administered Lecumberri. Newcomers were housed in crowded cells and received jobs ranging from menial to revolting. The uncomfortable and unpredictable conditions gradually allowed prisoners to understand that bribes could make their prison stint tolerable. ${ }^{32}$ "Everything in prison could be bought. Whatever you wanted: a cell, bed, women, wine, drugs." In one especially revealing example, the DFS investigated the directors of the Ciudad Juárez penitentiary for taking payoffs of 30,000 pesos a week to host "nocturnal trips to bars and brothels of the city" for prisoners, including several political prisoners who could afford the fee. ${ }^{33}$ In Lecumberri, prisoners referred to their meals as rancho (rancid) because the food tended to be borderline spoiled. According to Bernardo, "[It] was tasty when it was warm, but when it got cold..." A prisoner with enough money could have meals delivered from area restaurants. Prisoners in some cellblocks had access to

29. Adolfo Gilly, La revolución interrumpida, 2nd ed. (Mexico City: Ediciones Era, 20015).

30. AGN DFS, exp. 100-10-16, leg. 11, p. 236 (September 3, 1975). The "Klause" referred to is Karl von Clausewitz, a Prussian officer in the wars against Napoleon.

31. Ibid.

32. This type of bribery was common in prisons throughout Mexico. See for example AGN DFS, exp. 100-12, leg. 54, p. 67 (May 15, 1977).

33. AGN DFS, exp. 100-5, leg. 71, p. 261 (January 6, 1979). For a similar investigation of the Reclusorio Oriente, see exp. 53-2, leg. 8, p. 216 (February 28, 1979). 
kitchens and could cook their own food. "You paid for your meals, you paid for your cell; because if you didn't pay for the cell, you lived in a barracks. They charged you to keep a television, a radio, a typewriter." When one of his comrades either refused or could not pay, the guards put him in the common barracks, nicknamed la cebollita (the little onion), where he slept with about 60 other prisoners. They took away his shoes, and when his feet became infected with blood and pus from walking barefoot, they refused to take him to the infirmary.

Bernardo concluded that "Lecumberri was one big business." 34 Much like torture, corruption was a historically established practice inside prison walls. Bribes fed the tenuous impression of a more flexible existence for prisoners who could afford them and instilled fear among those who could not. Inmates' friends and families also grew to understand the incongruous coexistence between being in prison and the flexibility bribes afforded. Prisoners could call their families once a week. Family and friends could visit on Tuesdays and Sundays; lawyers could visit the other days. Even though it was not officially permitted, guards allowed family to visit on the other days as well because they brought money to the prisoners that they could then use to pay for privileges. Bernardo's father, for instance, would frequently come with food to have lunch with him during weekdays.

If their cellmates agreed, prisoners could have conjugal visits with their spouses. Visiting hours ended at 2:00 PM weekdays and 6:00 PM on Sundays, meaning prisoners could spend substantial portions of their days with loved ones. Aside from the prison officials and guards pocketing the money, this flexibility allowed prisoners to feel like they were not in prison for some periods: it conferred a sense of normalcy. It also made prisoners adhere to the rules, including following orders and paying the guards on time, for fear visits would be restricted. Political prisoners also sent messages in and out of the prison through their visitors. One man visiting a political prisoner in Oblatos was arrested in June 1977 while attempting to sneak out with a message from one of his comrades hidden in his shoe. ${ }^{35}$ Officials confiscated Trotskyite pamphlets from several visitors in March 1970; these were to have been used for education and recruitment of fellow prisoners. ${ }^{36}$

34. Alberto Ulloa Bornemann describes a similar bribery process in Ulloa Bornemann, Surviving Mexico's Dirty War: A Political Prisoner's Memoir, Arthur Schmidt and Aurora Camacho de Schmidt, trans. and ed. (Philadelphia: Temple University Press, 2007), 138-140.

35. AGN DFS, exp. 11-233, leg. 4, p. 45 (June 23, 1977)

36. AGN DFS, exp. 53-2, leg. 2, p. 89 (March 9, 1970). 
Money and good behavior allowed prisoners to negotiate with their captors and ease the burden of their confinement-within limits. Such negotiations demonstrated that prison administrators, despite being agents of the government, acted with a certain, self-interested autonomy and interpreted the dictates from higher-level officials with some discretion. Administrations varied. According to Alfredo Ulloa Bornemann, administrators at the Reclusorio Oriente proved more lenient than those at Lecumberri or Santa Martha Acatitla. ${ }^{37}$ This apparent looseness belies what could also be a brutal existence behind prison walls that included incidents when prison officials lost control. Conflicts erupted between imprisoned members of different guerrilla groups or between political prisoners and common prisoners. ${ }^{38}$

An April 1977 riot between political and common prisoners at Oblatos began when officials ordered a surprise search of the cellblocks for reported drugs. ${ }^{39}$ Inmates blockaded their cellblocks and battles ensued between different groups of prisoners and guards. The resulting report concluded that the source of the conflict lay in disagreements over the distribution of drugs among prisoners by two groups: the Subversives and the Jackals. Both groups distributed and consumed narcotics, including heroin and paint thinner. The report further speculates that the Subversives used drugs to attempt to recruit common prisoners to their cause in the hopes that, through indoctrination in Marxism, they would formally join the group once released. ${ }^{40}$ This cycle of unrest at Oblatos continued until October 1977, when prison officials and the military finally regained control of the facility. ${ }^{41}$

Political prisoners could opt for more drastic actions to improve their situation if day-to-day negotiations did not work. Hunger strikes were one of the most common forms of civil disobedience. ${ }^{42}$ A group of 85 political prisoners in Lecumberri, including the writer José Revueltas, the 1968 student movement leader Eli de Gortari, and longtime rural activist Ramón Danzos Palomino, went on a hunger strike in December 1969 to improve their treatment and call for their release. ${ }^{43}$ They managed to mobilize students, political figures,

37. Ulloa Bornemann, Surviving Mexico's Dirty War, 12, 170-172.

38. AGN DFS, exp. 53-2, leg. 1, pp. 199-207 (January 3, 1970); exp. 100-10-28, leg. 1, p. 25 (February 12, 1974); exp. 100-15, leg. 42, p. 33 (March 21, 1977).

39. AGN DFS, exp. 100-12-28 L2, pp. 71-79 (November 10, 1977). This riot came on the heels of an earlier riot in April 1977 that also included political prisoners. See exp. 100-12, leg. 53, p. 133 (April 27, 1977).

40. Ibid., pp. 77-78; AGN DFS, 100-12, leg. 2, pp. 74, 134-141 (October 12, 1977).

41. AGN DFS, exp. 100-12-28, leg. 2, p. 71 (October 19, 1977).

42. AGN DFS, exp. 30-72, leg. 2, p. 236 (November 16, 1960).

43. AGN DFS, exp. 100-5-1 exp. 28, p. 28 (December 12, 1969), p. 95 (December 13, 1969); exp. 11-4, leg. 100-, p. 86 (December 2, 1969). 
and labor activists throughout the country to support their efforts. ${ }^{44}$ Family members of political prisoners, through groups such as the political prisoner advocacy group Comité Pro-Presos Políticos, also lent their support and joined protests inside Lecumberri. On January 1, 1970, approximately 300 family members, including women and children, who had come to Lecumberri to support the hunger strikers, were beaten up as guards stormed the prison, attempting to intimidate the protestors. ${ }^{45}$ Bowing to public pressure, the government soon agreed to release a number of political prisoners.

Hunger strikes of various lengths continued throughout the decade to demand better treatment and the release of prisoners. A 1973 hunger strike in the Acapulco penitentiary went on for several months and grew to include 110 prisoners demanding the release of political prisoners. ${ }^{46}$ The DFS kept track of the prisoners who participated, their health status, and whether or not they had support from their families or others outside the prison walls. ${ }^{47}$

The DFS files of the 1970s are riddled with attempts by prisoners to escape. Most of them failed, and some included or were orchestrated by political prisoners. ${ }^{48}$ Digging tunnels and bribing officials were among the more common escape tactics. Other more dramatic efforts included the launching of a wholesale assault on a prison by a guerrilla group to liberate one of its leaders. For example, the LC-23S staged a failed attempt to free four of its members from a Sonora prison in $1975 .{ }^{49}$ In a raid on an LC-23S safe house in Ciudad Juárez, the DFS discovered plans for a mass escape from the state penitentiary. ${ }^{50}$ Prison officials and DFS officers punished those who failed at their escapes to discourage any who might follow their example. After one escape attempt in which prisoners tried to tunnel out of their cells at the Acapulco penitentiary, a political prisoner, in the words of the DFS agent, "showed a great deal of nervousness. When the people arrived to interrogate him, he started yelling that he was ready to be killed." 51 Occasionally an attempt succeeded, as occurred in the dramatic escape of six LC-23S members from Oblatos in January 1976, which left three police officers dead. ${ }^{52}$

44. See for example AGN DFS, exp. 100-6-1, leg. 16, p. 80 (December 18, 1969, Coahuila); exp. 100-5-1, leg. 28, p. 76 (December 12, 1969, Chihuahua); exp. 100-14-1, leg. 18, p. 272 (December 19, 1969, Michoacán); and exp. 100-25-1, leg. 6, p. 350 (January 16, 1969, Tabasco).

45. AGN DFS, exp. 100-26-1, leg. 16, p. 238 (January 19, 1970).

46. AGN DFS, exp. 100-10, leg. 41, p. 303 (January 23, 1973); ibid., leg. 43, pp. 178-182 (July 26-27, 1973).

47. For example, AGN DFS, exp. 100-15, pp. 42, 51 (March 22, 1977).

48. AGN DFS, exp. 11-12-28, leg. 1, p. 222 (June 18, 1976), describes a failed escape attempt of political prisoners at Oblatos.

49. AGN DFS, exp. 11-235, leg. 24, p. 280 (January 26, 1975).

50. Ibid., leg. 36, pp. 2-22 (February 14-25, 1976).

51. AGN DFS, exp. 100-10-1, leg. 76, pp. 60-63 (August 25, 1978).

52. AGN DFS, exp. 100-235, leg. 35, p. 203 (January 22, 1976); exp. 11-235, leg. 36, p. 76 (March 15, 1976). 
From the beginning, families suffered alongside their imprisoned loved ones. In a riot among Lecumberri prisoners in January 1973, 30 family members of political prisoners on a hunger strike were trapped inside the cells overnight as police swarmed the facility to regain control. ${ }^{53}$ As in the Southern Cone dirty wars, it was prisoners' families who offered the first significant resistance to the government's use of repression against its citizens. They did so in the aftermath of the 1968 student mobilizations and continued throughout the third stage of Mexico's dirty war. Parents formed support organizations such as the Association of Parents and Family Members of Political Prisoners to raise public awareness and call in a common voice for the release of their sons and daughters. ${ }^{54}$ They hand-delivered petitions to government leaders, organized rallies, and camped outside the prisons to demand better conditions for their children. Parents were especially active at Oblatos between 1976 and 1978. ${ }^{55}$ They wrote to authorities and staged rallies complaining that their imprisoned children were enduring terrible living conditions, beatings, threats, and other abuses at the hands of police and prison authorities. They denounced the fact that police showed up at their homes late at night, hauled their children away to an unknown location, and tortured them as an act of intimidation. ${ }^{56}$ Families who organized to help prisoners experienced repression that increasingly targeted them for their activism. Parents in Guadalajara nevertheless continued unabated in their defense of their imprisoned children, rallying hundreds of supporters outside Oblatos. ${ }^{57}$ The imposition of suffering on families guaranteed a net of punishment that went far beyond the incarcerated and nurtured a continuum between what took place inside prison walls and broader society.

DFS reports indicate the presence of infiltrators and informants among political prisoners. Although these reports do not contain names of those who relayed information, the level of detail suggests it came from inside the cellblocks. ${ }^{58}$ As the 1970s progressed, these infiltrators, informants (called madrinas, or godmothers), and some tortured activists helped refine the government's list of targeted individuals. Madrinas could, as Roberto González Villareal has noted, "be voluntary or not; they could be paid informants or not; oftentimes they were deserters from Lucio's group or were being threatened." 59 The

53. AGN DFS, exp. 53-2, leg. 1, p. 257 (January 5, 1970).

54. AGN DFS, exp. 100-12-1, leg. 42, p. 87 (February 7, 1976); exp. 100-12-28, leg. 2, p. 19 (June 26, 1977); leg. 2, p. 26 (September 2, 1977).

55. AGN DFS, exp. 100-12, leg. 59, p. 101 (October 23, 1977).

56. AGN DFS, exp. 100-12-1, leg. 42, p. 88 (February 7, 1976).

57. AGN DFS, exp. 100-12, leg. 55, p. 272 (June 29, 1977).

58. AGN DFS, exp. 53-2, leg. 2, leg. 135 (March 25, 1970).

59. Roberto González Villareal, Historia de la desaparición: nacimiento de una tecnología represiva (Mexico City: Editorial Terracota, 2012), p. 105. 
simple fact that a tortured detainee or a madrina pointed you out was enough justification to be picked up. David López Valenzuela became an informant inside Oblatos after he was picked up in 1974. He helped the DFS confirm that a bomb that had failed to detonate belonged to his guerrilla group and gave evidence that supported the targeting of high-level individuals for kidnappings and assassinations. A former political prisoner told Elena Poniatowska that López Valenzuela had identified turned him to DFS officers, who picked him up, brutally tortured him, and sent him to Oblatos. ${ }^{60}$ Although he was blindfolded during the torture sessions, he knew that López Valenzuela stayed in the room to prompt his interrogators with the questions to ask.

Prisons afforded prime opportunities for surveillance because they allowed for the infiltration of guerrilla groups and the interception of information from comrades on the outside. ${ }^{61}$ Sergio Aguayo tells of the case of Alicia Valdez Rodríguez, the wife of Pedro Cassian Olvera, a guerrilla member imprisoned in Oblatos. She acted as a go-between for messages from those inside the prison with comrades on the outside. After detaining and torturing her, DFS agents raided the guerrilla safe house where Rubén Mayoral, another guerrilla member, was hiding. In the ensuing gunfight, Rubén shot and injured one of the DFS agents before escaping. In retaliation, agents took his 70-year-old father prisoner and disappeared him. ${ }^{62}$ In another case, officials arrested an individual because he paid daily visits in 1974 to a political prisoner at the penitentiary in Monterrey, Nuevo León. ${ }^{63}$ After "interrogating" him, they concluded he had been the messenger between a group of political prisoners and guerrilla members orchestrating a prison escape.

One especially devastating letter was intercepted by prison officials as it was thrown over the Acapulco prison wall in February 1974. It reveals the dawning awareness among political prisoners that their fellow inmates were being disappeared. The prisoners' letter reported that penitentiary officials had burst into a cell at 2:00 AM and hauled away two of their comrades. The prisoners begged whoever retrieved the letter to take action to locate them. ${ }^{64}$

\footnotetext{
60. Elena Poniatowska, Fuerte es el silencio, 3rd ed. (Mexico City: Ediciones Era, 1981), 109-110.

61. Aguayo, Charola, 184

62. Ibid., 184-85.

63. AGN DFS, exp. 11-235, leg. 14, p. 50 (May 8, 1974).

64. AGN DFS, exp. 100-10-28, leg. 1, p. 16 (February 9, 1974).
} 


\section{The Torture Session}

According to Marnia Lazreg: "The grammar of torture is as rich as it is specialized." ${ }^{65}$ She is alluding to the many forms of brutal violence inside prison walls. While Bernardo was in prison, two escape attempts led to a security crackdown. Beatings at the hands of prison gangs were common. While most gangs were made up of presos comunes, several included political prisoners that had crossed over to delinquency. Gang members would pounce on weaker prisoners to take food and other goods they had been left by their loved ones. Yet for Bernardo it was the official violence that stood out: "Police used torture to discover the truth and they didn't use it against only political prisoners; it was a tradition of the Mexican police to use torture. It was popular knowledge that in the hands of the police you could be tortured." When pressed on how it could be common knowledge, Bernardo clarified that those inside prisons sent word to those on the outside of what they suffered. For example, Lecumberri political prisoners handed out pamphlets in July 1969 to denounce their torture and ask for an end to their degrading treatment. ${ }^{66}$ Bernardo went on to explain: "The more you became involved, the likelier it was that you could be detained, that you could die in battle or while being tortured, which is what we thought had happened to many comrades since we still didn't know that people were being disappeared."

Bernardo's statement reflects a common understanding among Mexicans: torture had a long history in Mexico and was a practice not only well established in prisons but tolerated and even promoted. Nevertheless, the torture that Bernardo and his comrades experienced had a decidedly modern twist that characterized the third and most violent stage of Mexico's dirty war. Their torture was designed to decimate the burgeoning threat posed by guerrilla groups in the 1970s; thus, it was harsher than that experienced by those jailed in the aftermath of the 1968 student movement.

There are no written records available that document the precise steps interrogators followed when torturing an individual. What we do know about torture comes primarily from testimony given to human rights organizations such as the $\mathrm{CNDH}$ and from interviews with survivors. Taking stock of these testimonies shows us that there was a certain art to interrogating an individual as well as a growing arsenal of techniques, some inspired by the tactics of other dirty wars throughout Latin America and some with uniquely Mexican

65. Marnia Lazreg, Torture and the Twilight of Empire: From Algiers to Baghdad (Princeton: Princeton University Press, 2008), p. 132.

66. AGN DFS, exp. 53-2, leg. 1, p. 134 (July 21, 1969). 
overtones. As González Villareal has written, the act of detention was often the first step in the process that tended to culminate with the imprisonment or disappearance of an individual. ${ }^{67}$ Officials used the element of surprise to kidnap individuals, sometimes in broad daylight or a night raid of their homes, and tended to work in groups of up to 30 to guarantee the detainee's successful capture. ${ }^{68}$

Once under police control, the prisoner would be transported, usually in an unmarked vehicle, to a detention center. Of these, the center called CM-1, in Mexico City, seems to have been the one most used for coordinating the use of torture. In September 1961, Interior minister Gustavo Díaz Ordaz mandated the creation of a special prison on the grounds of CM-1 to house political prisoners exclusively. ${ }^{69} \mathrm{CM}-1$, according to its original mandate, was to be run by the military and not by bureaucrats ignorant of the threat political prisoners represented. ${ }^{70}$ More specifically, CM-1 would serve as a clearinghouse where it would be determined which prisoners would be sent to clandestine prisons and there tortured to give information. Prisoners thus spent short stints of time at CM-1, usually weeks to months, before being released, disappeared, or relocated to a traditional prison.

There were other clandestine detention centers. The basement of the DFS building had cells for the exclusive use of political prisoners. The barracks of the mounted police squad in the Tlatelolco public housing project was also at the disposal of the DFS and Mexico City's secret service. Both Bernardo and Saúl spent time there after they were picked up, Saúl in 1972 and Bernardo in 1975. Saúl remembers that this clandestine prison had an office, a yard, and two hallways with cells facing each other, for a total of 20 cells. Bernardo recalled that it was nicknamed the "train" because the cells were small and lined up one after the other. Clandestine prisons sometimes double as torture centers. Officers used the drinking troughs of the police horses to dunk prisoners. They threw blindfolded prisoners in the stalls with the animals while they were eating and told prisoners they would be bitten.

Saúl was one of about 20 militants from an urban guerrilla group rounded up by police in October 1972. They picked him up as he walked across a Mexico City university campus at 8:00 AM and took him to a clandestine prison.

67. González Villareal, Historia de la desaparición, 45-57, tracks the escalation and the geographic distribution of disappearances from 1970 to 1974.

68. Ibid., 59-60.

69. AGN-DGIPS, Dirección General de Investigaciones Políticas y Sociales, Vol. 2860, exp. 10 (September 11, 1961). For CM-1 in its early years, see Condés Lara, Represión y rebellion, vol. 1, 125-190.

70. Ibid. 
Saúl's experience with torture lasted ten days, with most days including three sessions with the torturers. These sessions were always under the command of a senior officer and included up to three other officers. "Strapped to a board, sitting down, completely tied up, blindfolded, and that's when the questions start. At the outset [it's] 'Who are you?' 'What did you do?' 'In what did you participate?" At the beginning, torture is a physical experience, according to Saúl, "to soften you, to take you down because, in hurting the body, you lower everything and especially a person's morale. They denigrate you with beatings, with torture, by making you feel pain and feel suffused with terror." As the session advances, he continued: "They [the torturers] become more refined, the questions are more concrete, and they start leading their investigation where they want to go." For Saúl, this was the point at which he met DFS official Miguel Nazar Haro, whose questions were accompanied by a different kind of torture: "They are more precise in the tissues they touch because they get to know where you are tough and where you are weak. Maybe you can withstand beatings, but you can't take the pozo (water immersion). Maybe you can put up with some of the pozo but you can't resist electrical currents." They start fine-tuning their treatment and, once they discern a prisoner's weaknesses, they double that part of the treatment with almost surgical precision."

It was difficult to determine the length of a torture session. As Saúl described it, "You lose the sense of time." Bernardo recalled that the guard had a radio at full volume tuned to a station called La Hora, which announced the time every minute with a distinct chime, between advertisements. "As time goes on, you get all mixed up and all you hear is that damn chime. It's a way to break you." Saúl and Bernardo had noted that if they waited at least 24 hours before breaking down and naming names, their comrades might have enough time to avoid capture. Bernardo remembers that the initial questions were about the locations of meetings and safe houses so that officers could round up more comrades before word got out and they fled. A month after his initial detention and well into a torture session, Ulloa Bornemann described the vehicle driven by two of his comrades, believing they would have gotten rid of it by the time they were apprehended. They had not, and soon after he had divulged their names and vehicle description, they were picked up and brought into CM-1. He later described listening to one of them being tortured and the extreme guilt he felt at having being part of his capture. ${ }^{71}$

A torture session would frequently include varied techniques to inflict pain with surgical precision. ${ }^{72}$ Bernardo's weakness was hanging; what prisoners referred

71. Ulloa Bornemann, Surviving Mexico's Dirty War, 121-122.

72. For an etymology of these terms, see Feitlowitz, Lexicon of Terror, 59-71. 
to as the pollo rostizado (rotisserie chicken). "They hung me from my arms and one of the soldiers takes down my right arm and leaves me hanging from my left hand and he left me like that for days." He suffered long-term injuries from prolonged hanging. The pozo (the well) was a common waterboarding technique. Ulloa Bornemann described how "several agents submerged my head backward in the cold and dirty water of the basin." 73 Some prisoners did not survive the pozo. Ulloa Bornemann recalled that officials brought a young man-educated, as his speech revealed-from somewhere else to the basement [of CM-1]. "I never saw him, but I know that they submerged his head several times in a steel drum full of water until they drowned him." One of Elena Poniatowska's informants recalled how the picana (electric prod) was used: “[It] was inserted in men's anuses, and into women's anuses and vaginas. It's also applied to testicles, nipples, lips, gums, to all soft parts." ${ }^{, 75}$ Often the picana would be used in combination with the pozo, or following it. The prisoner would be blindfolded with hands or feet restrained, sometimes naked, soaking wet, or standing in a pail of water. ${ }^{76}$

As Bernardo noted, doctors were often around to ensure a prisoner could withstand torture without dying. A doctor was brought in to quickly assess the gunshot wound on Saúl's leg after he was picked up and gave him what he imagined was an antibiotic pill. Saúl received no additional care for his leg wound. Prisoners spent so much time blindfolded that many who were detained have a scar on the bridge of their nose from where the cloth rested. As Jesús Morales, a former political prisoner, recounted in his interview with Sergio Aguayo, "They never took it off, and you're screwed because they get you wet, they shove your head in toilets and then it dries, it gets sore, infected."77 Bernardo's eyes remained bandaged most of this time, the blindfold coming off only when his eyes grew severely infected from being closed for so long. Domingo Estrada Ramírez remembered that the only time they took the bandage from his eyes was to sign a confession; he could not see because his eyes had been shut for so long. ${ }^{78}$ Saúl, after almost ten days of captivity and still blindfolded, was dragged onto a helicopter. As the helicopter rose in the air, the officials persisted in their questioning. Realizing that his answer was not going to change, the torturers strung up his hands and hung him out the door. Saúl remembers feeling the wind on his body and the sensation of hanging, but he could see nothing.

\footnotetext{
73. Ulloa Bornemann, Surviving Mexico's Dirty War, 31

74. Ibid., 29.

75. Poniatowska, Fuerte es el silencio, 106.

76. Ibid., 42.

77. Aguayo, Charola, 186.

78. Poniatowska, Fuerte es el silencio, 110
} 
Bernardo's experience was different from Saúl's. After being picked up, Bernardo was relocated to several different prisons, clandestine and official. Instead of conducting an intense ten-day session, officers tortured Bernardo every third day for approximately four weeks. Another former prisoner recounted what happened to him after he was picked up in Ciudad Juárez and transferred to a clandestine prison in Mexico City in May 1978: "Mineral water through the nose, immersion of the head in a pail of water, electric shocks to private parts, blows in series of ten for each question that we answered that we didn't know. [The blows] were given methodically with a rubber bar or other object to the shoulders, head, face, chest, back, legs, rear end, knees, shins, feet, arms, elbows, hands, and toenails. Other days the torture was different. Some[times] persuasion, psychological torture, like simulated killings, death threats to our families."79

In contrast to the two earlier stages of Mexico's dirty war, women figured on the lists of those detained, tortured, and disappeared in this third stage. A DFS list of political prisoners from August 1978 includes 117 individuals, organized under the names of their respective guerrilla groups, after which follows the location of their detention. ${ }^{80}$ The list contained the names of 27 women among the 15 guerrilla groups. Adela Cedillo has concluded that 43 women were disappeared, at least 20 assassinated, 89 incarcerated, and seven exiled. ${ }^{81}$ Bernardo reported that three of the 16 people with whom he was originally imprisoned were women. Torture was a different experience for women, most tellingly because sexual violence, including rape, was a common feature in their sessions. A former female guerrilla member wrote, "Besides the beatings and waterboarding and everything else, one had to endure very severe sexual aggression, which leaves indelible marks ... I still wake up screaming." 82 Another female victim recalled, "They took me in front of my husband, who was also naked, they were applying electrical shocks to his testicles. They threw me on the ground in front of him and hit me, then hung me by my nipples. Later they introduced a metal prod into my vagina and started applying electrical shocks to my vulva and nipples." ${ }^{83}$ As sociologist Marnia Lazreg explains, "Sex, in particular rape, afforded torturers an efficient and reliable way of breaking down an individual by systematically inflicting pain and humiliation, while desexing the victim." 84 In other words, sex-oriented torture techniques were a

\footnotetext{
79. CNDH, Informe especial.

80. AGN DFS, exp. 11-240-78, leg. 11, pp. 168-174 (August 2, 1078).

81. Calderón and Cedillo, Challenging Authoritarianism, 180-181.

82. Rayas, "Subjugating the Nation," 609-624.

83. CNDH, Informe especial.

84. Lazreg, Torture and the Twilight, 142-144.
} 
routine part of the interrogators' arsenal—one that gave the interrogator a clear sense of domination over the victim.

In what appears to have been exceedingly common in the Mexican case during this period, the government targeted family members, including children and parents, for their relationship with guerrilla members. ${ }^{85}$ In 1975, the DFS detained Margarita Andrade Vallejo's parents and three siblings for up to 12 days in a clandestine torture center. After learning of what happened to her family, Margarita committed suicide. ${ }^{86}$ In another case, a man was brought before his brother in a clandestine prison to identify him as a guerrilla member. His brother was "a foul-smelling bloody mess," his eyes "so swollen that he could barely open them to see," and his "mouth so battered he could hardly get the words out." 87 The threats or actual torture of family members had been a common practice as far back as $1968 .^{88}$ After a month of being tortured, Bernardo knew that he was one of 16 people held in the clandestine prison at the mounted police barracks. Once they had finished with them, they were rounded up to be transferred to Lecumberri for formal processing. Only 13 remained, suggesting that three had been disappeared; one of these whom was the father of a guerrilla leader.

Not only did agents routinely threaten children of activists, but they went so far as to torture them in front of their imprisoned parents to get them to talk. We do not know the full extent of child torture or when it entered the arsenal of tactics. A former political prisoner testified that officers brought her 14-monthold baby girl before her and proceeded to "apply electric shocks all over her little body." 89 The FEMOSPP report lists the cases of 204 children incarcerated primarily for the purpose of breaking their parents. At least eight female political prisoners were pregnant when detained and four gave birth while in prison. ${ }^{90}$ In an unknown number of cases, children were given up for adoption after their detention. The warden of the Women's Prison in Mexico City reported to the DFS that one political prisoner had made demands to learn the whereabouts of her young son after she read in the newspaper that he was in the custody of the DFS. ${ }^{91}$ Several cases of disappeared children who were later found by their families garnered attention in the media. ${ }^{92}$ Nevertheless, questions regarding

85. I am not the first to take note of this pattern. See Jorge Mendoza García, "La tortura en el marco de la guerra sucia en México: un ejercicio de memoria colectiva," Polis 7:2 (2011): 7.

86. Rayas, "Subjugating the Nation," 177.

87. CNDH, Informe especial.

88. Poniatowska, Fuerte es el silencio, 108, 111, 113; Nexos, October 1993.

89. $\mathrm{CNDH}$, Informe especial.

90. Calderón and Cedillo, Challenging Authoritarianism, 180-181.

91. AGN DFS, exp. 11-235, leg. 13, p. 46 (August 29, 1978).

92. Washington Post, January 5, 2005; Proceso, January 16, 2005. 
the violence experienced by children, as either direct or indirect victims, remain unanswered.

\section{The Torturers}

Saúl reported that he had met two different types of torturers while at CM1. The first knew how to torture and clearly had ample experience doing it with what he termed "common delinquents." This first type fit the model of the abusive policeman in the political cartoons and social satire of Eduardo del Río, better known as Rius. Rius brought alive this character first in his cartoon series Los supermachos and later in Los agachados, which he published from 1968 to 1977. This policeman followed orders, partook of the spoils of a corrupt political system, and derived his masculine identity by following the edict of "machos, borrachos y compachos" ("studs, drunks, and good old boys"). ${ }^{93}$ These officials did not have the vocabulary to understand political prisoners. Saúl reported that his guerrilla group had numerous cells housing from six to twelve individuals each. However, the cells did not know the other ones to avoid a total collapse of their organization if one of them was compromised by detention or infiltration. These first torturers also took his inexpensive watch for their own use and periodically rifled through his pockets to ensure they had not missed anything they could take.

Saúl met the second type of torturer several days into his incarceration. A DFS agent brought a chair and placed it in front of his cell. Saúl was no longer blindfolded. "The agent had a file and asked me to get closer to the bars so we could talk, even offered to get me a chair so I could be more comfortable. He took out the first page from the file, my record," and noted that they had studied at the same school, though the agent had been a few years ahead. The agent rattled off the names of several teachers and "asked if I remembered them. He is asking me where I have been, but he already has everything written down." After reviewing Saúl's time in university, the DFS interrogator went on to the file they had built on him since he had joined a leftist movement, in 1967. The file contained photographs and information that came from a conversation Saúl had had with his high school principal after he was brought in to talk about whether or not he had been involved in the bombing of the Bolivian embassy in the aftermath of Che Guevara's assassination. In contrast to the first torturer, the DFS agent knew Marxist terms and could handle a political conversation.

93. Harold Hinds Jr. and Charles M. Tatum, Not Just for Children: The Mexican Comic Book in the Late 1960s and 1970s (Westport, Conn.: Greenwood Publishing Group, 1992), 70-81. 
Marnia Lazreg discusses these two types of torturers in her study of "depth interrogation" among more educated victims of French repression in Algiers. As she explains it, both types of torturers play an important role in breaking down an educated prisoner, similar to what happened to Bernardo, Saúl, and Alberto. The more physical and less psychologically oriented officers used prolonged bodily pain to weaken the person, so that they would be more vulnerable to the tactics of the more psychologically oriented interrogator. The interplay between the two types of torturers allows for depth interrogation because, as Lazreg notes, it "disrupts the organization of thoughts and shocks the mind out of its secrets." 94 The second, more specialized, torturer tended to come from the ranks of the DFS agents. Of these, Miguel Nazar Haro figures prominently in the descriptions of torture sessions of many individuals and represents the second type of torturer. ${ }^{95} \mathrm{He}$ was also one of the few to declare publicly that he had played such a role. ${ }^{96} \mathrm{He}$ had a long and distinguished career inside the DFS and headed the agency between 1979 and 1982. After training in Washington, DC, he established the Special Investigations Group C-047 in November 1965 to track and infiltrate guerrilla groups, such as LC-23S. ${ }^{97}$ His success rested on making Grupo C-047 a clearinghouse for all information, which was then used to orchestrate operations to bring down the guerrilla. ${ }^{98}$ He represented the DFS inside the White Brigade, also known as the Special Brigade, established in June 1976 with the exclusive aim of destroying the LC23S. ${ }^{99}$

In Saúl's words, Nazar Haro was both a policeman and a public official. He knew how to behave according to his rank and approached the torture session with a certain "coldness, serenity, and calculation." In a session with Nazar Haro near the end of his ten days, Saúl was tortured in a new way. Rather than immersing him in water and threatening him with drowning, they shoved his head in a toilet filled with feces in an act of total humiliation: "You are shit and you are in the shit." Afterward, they sat him on a chair and told him, "The worst is yet to come and you are the only one that can save yourself from it." Into the room they ushered a young woman dressed in a traditional nurse's outfit. Nazar Haro asked Saúl if he knew that one of his heroes, Fidel [Castro, from Cuba], did not have one of his testicles, and then said that Saúl had better

94. Lazreg, Torture and the Twilight, 138.

95. Nazar Haro was indicted in 2004 through the FEMOSPP, but his case was dismissed in 2006. ADN Político, January 27, 2012; Proceso, September 9, 2013.

96. For interviews he gave to the press, see La Jornada, February 4, 2009, January 28, 2012, and January 29 , 2012; and Proceso, October 29, 2000. For more on such confessions, see Leigh Payne, Unsettling Accounts: Neither Truth nor Reconciliation in Confessions of State Violence (Durham: Duke University Press, 2008), $173-195$.

97. Aguayo Charola, 125.

98. Ibid., 182-184.

99. La Jornada, July 7, 2008. 
give him the names of the contacts in the north. Saúl replied that he did not know any such contacts. Saúl remembers Nazar yelling, "Lift him up. Tie him down. Open his legs," and, as the nurse came toward him with her surgical kit, shouting, “¡Órale! now we get to immortalize him. We are going to give these assholes some heroes. ¡Chingátelo! (Fuck him!)” Saúl then felt cold on his skin, and they removed his testicle. This was his first and only meeting with Nazar Haro. Even though men and women experienced sexual forms of torture differently, they were bound, as Lazreg concludes, by the fact that "sex is at the core of torture." $" 100$

The number of political prisoners went down after 1976. As a result, Bernardo notes, there were not enough of them to segregate them separately from the rest of the prison population, and he was moved to a cellblock with the common prisoners. The smaller number also meant a smaller target: after 1976, guerrilla members "knew that if they picked you up, you would be killed or tortured and then disappeared." When he was at the Tlatelolco clandestine prison, Bernardo recalls seeing the stereotypical "chubby" police officer along with what appeared to be a "new breed of officer: young, different from the stereotype, thin, strong: the cazadores (hunters). They would walk by with shotguns and say 'Let's go hunting."'101 As Bernardo was being put on a transport to Lecumberri in June 1975, Nazar Haro pulled him aside and told him to send a message to his comrades: Bernardo's would be "the last group that makes it to the prison," suggesting that from now on anyone captured would be killed. Bernardo stated that from then on, a few individuals here and there were captured and transported as political prisoners, never a group of more than two or three, and it became more common to have their members disappeared.

\section{CONCLUSION}

In September 1978, President José López Portillo declared an amnesty that ordered the release of political prisoners. ${ }^{102}$ Some remained detained because they had committed crimes beyond the scope of political activism, including robbery, kidnapping, and murder. Nevertheless, the announcement in 1978 and the disbandment of the DFS's White Brigade in 1980 set in motion the end of Mexico's dirty war, which concluded with López Portillo's departure in 1982. The amnesty did not, however, signal an end to political violence

100. Lazreg, Torture and the Twilight, 143 .

101. This refers to the Halcones, a paramilitary group that in June 1971 attacked a group of student demonstrators in Mexico City, leaving an unknown number injured or killed.

102. AGN DFS, 100-12, leg. 64, p. 294 (September 1, 1978). 
and the start of a more peaceful post-guerrilla era. As Roberto González Villareal has pointed out, it continued as police at all levels confronted growing mobilizations from social sectors protesting the burden of the economic crisis, as well as growing disaffection with the PRI-led state's authoritarian ways. ${ }^{103}$

Though the French coined it in Algeria in the 1950s, the term "dirty war" readily transfers to what is known as the long 1970s. ${ }^{104}$ We think of dirty wars in Latin America as emerging out of the failure of earlier efforts to institutionalize reforms, some with populist overtures, or revolutionary transformations. This failure made way for the politics of intimidation and state terror, where sectors of the military infantilized civil society by stressing what it meant to be an acceptable member. In this context, the security risk was internally derived-domestic in nature and fed by the international paranoia of the Cold War-which made it all the more threatening and deserving of extraordinary measures. As Greg Grandin explains, "Lacking not only a monopoly of legitimate violence but the necessary capacity for legitimate repression to counter seemingly inextinguishable mass mobilizations, security forces imported from the United States (as well as from South Africa, Israel, and France) new repressive technologies to national violence." 105 Aside from disappearing or outright killing problematic members of society using these transnational repressive technologies, the dirty war entailed additional layers of repression to train society into obedience, which included torture, detention, censorship, and reference to supposed threats of guerrillas and assorted imagined enemies.

Peruvian writer Mario Vargas Llosa has referred to Mexico as the "perfect dictatorship," precisely because the regime used a variety of methods to maintain control. The government co-opted intellectuals, promoted an international image as a progressive haven for exiles from other countries, controlled the media, and channeled popular sectors into a corporatist system that diffused challenges. These methods also entailed the long-term orchestrated deployment of repression that stretched from the late 1940s into the 1970s. In these decades, we see the strategic disappearance of individuals as well as the wide-scale though episodic use of detention, torture, and later on disappearance to nurture a culture of fear.

103. Villareal González, Historia de la desaparición, 133-140.

104. My view of dirty war comes from conversations with Steve Stern as well as his book Remembering Pinochet's Chile: On the Eve of London 1998 (Durham: Duke University Press, 2004).

105. Greg Grandin, The Last Colonial Massacre: Latin America in the Cold War (Chicago: University of Chicago Press, 2004), 13. 
To understand the prolonged use of these practices, we turn to the notion of low-intensity warfare with its selective enforcement, clandestine legal and quasilegal methods, the lack of a clear enemy, and the dissemination of fear. Playing off this concept, we could thus think of the Mexican case as a low-intensity dirty war, as one way in which this self-reinforcing authoritarianism functioned and reproduced itself for so long. The framework of low-intensity dirty war allows us to track the evolution of repressive tactics that emerged in the third stage, from 1968 to 1982 , and study what was new and what was built on pre-existing practices of social control.

This article, with its focus on political prisoners and the use of torture, puts together the pieces of an exceptionally violent period in twentieth-century Mexican history. By way of conclusion, it is only fitting to return to the words of the historical subjects themselves, words that express how they understood this violence. In our interview, Saúl explained that torture represented asking the question of how much pain a person could withstand. Answering that question, according to Saúl, leads us to the conclusion that torture is a form of "state terrorism because it is all about destroying an individual." For him, torture represented going through "the last door." It meant "finding out ... the limits of human pain." Saúl added, "No one can say you won't talk if tortured because you don't know your pain threshold or which paths will most hurt you. Perhaps physically you are strong as an oak, a rock, but perhaps then they bring you your child, your father, your mother and they break you. Torture is florid." This analogy of violence as florid carries over to what made the dirty war, in particular its third stage, so successful. Mexico's own dirty war thus needs to be understood as a system of repression worthy of comparison to others in the region, even while recognizing its unique features.

Syracuse University

GLADYS MCCORMICK Syracuse, New York 